International

Medical Society

http://imedicalsociety.org

\title{
Nursing Cardiovascular Care to Potential Donor with Brain Death
}

Carla Daniele Mota Rêgo Viana1, Ligia Fernandes Scopacasa², Tatiana de Medeiros Colletti Cavalcante ${ }^{2}$, Bruna Michelle Belém Leite Brasil' Natália de Lima Vesco ${ }^{3}$, Natasha Marques Frota1, Camilla Pontes Bezerra1,

Débora de Araújo Moreira Varela', Jênifa Cavalcante dos Santos Santiago', Maria das Graças da Silva Guerreiro1, Lorena Maia Morais4, Isabelle Morais Braga ${ }^{5}$

\section{Abstract}

Objective: Identify and analyze the knowledge of nurses regarding the maintenance of the potential donor with brain death on the cardiovascular changes that it may present, Besides the care related to infectious aspects.

Methods: This is a descriptive study with a quantitative approach, with the sample of 82 nurses.

Results: It is noteworthy $85.4 \%$ of respondents said they feel prepared to assist these patients; however, we found high prevalence of partial knowledge among nurses interviewed on the subject in question

Conclusion: In that way, it is clear the need for educational activities and continuous improvement to health professionals on the subject, allowing an expansion of scientific knowledge and assistance qualified practice, resulting in more uniform and professional conducts an increase in the quality of offered organs.

\section{Introduction}

The donation and organ transplantation are related to each other and give possibility of the continuation of life through an attitude of soli-
1 Department of Nursing, Centro Universitário Estácio. Fortaleza, Brazil.

2 Department of Nursing, University of Fortaleza. Fortaleza, Brazil.

3 Department of Nursing, University Federal of Ceará. Fortaleza, Brazil.

4 Academic Nursing. Faculdade de Ensino e Cultura do Ceará, Fortaleza, Brazil.

5 Academic Nursing. Department of Nursing, Centro Universitário Estácio. Fortaleza, Brazil.

\section{Contact information:}

\section{Carla Daniele Mota Rêgo Viana.}

Address: Rua Eliseu Uchôa Beco, 600. Água Fria, Fortaleza, CE, Brazil, 60810 270.

Tel: +055(85)9145-2856

”profdanieleviana@gmail.com

\section{Keywords}

Brain DEATH; Nursing Care; Tissue Donor 
darity, whether it comes from a donor or a patient's family. Even though an odd relevance, the theme has been of interest to the scientific community for less than 60 years [1]

Thus, in recent years, panoramas, domestic and foreign, have shown much progress in the context of transplantation. In the United States of America (USA) in 2014, they have materialized over 29,534 organ transplants. In Brazil, the same aforementioned year, they conducted to 7,898 organ transplants, especially, so our country as the largest public system in the world of organ donation, behind, only the US [2].

Unfortunately, even with the level reached by Brazil as one of the greatest potential for organ donation, there is a discrepancy between the demand and the amount of donations. According to data published in September 2014 by the Brazilian Registry of Transplants (RBT), there are more than 29,021 patients waiting for a transplant [3].

In order to respond to the above data, many scholars try to indicate the impediments to the increase in organ transplants. Among the main obstacles, are the rejection of the families of potential donors (PD) for the donation; clinical disability due to unspecific causes of death, infectious diseases, among others; The industry fails to identify PD; and assistance to inadequate provided to the PD [4].

Through a dynamic process with many interconnected stages and dependent on the success of organ donation depends on each of these stages, from early detection of potential donor (PD), to the monitoring of post-transplant results. In Brazil, this process of capturing and organ donation is governed and regulated by Law No. 9,434/97 and Law No. 10,211/01, which establishes the guidelines of the National Transplantation of Organs and Tissues policy, determining the gratuitousness of donation, In addition to the criteria of the living and deceased PD.

There are three types of potential deceased donors: donor with recent heart stopped, donor with late heart stopped and the donor with Brain Death (BD) [5].

Given the complexity of capture and transplant procedure, several professionals are Involved in the transplant process. Thus, the nurse, in the donation process, exercises Function essential the care and maintenance of PD. Therefore, It is essential for the scientific understanding of the pathophysiological changes of the potential donor brain death3. Therefore, the work of nurses in the process of organ donation is regulated by resolutions of the Federal Council of Nursing (COFEN) No 200/97 and No. 292/2004, Which regulate the professional care nurse in the systematization of nursing care in the donation and transplantation of organs and tissues [2].

The primordial nursing care to be provided to the client with BD for maintenance this one like possible organ donor and Tissues are guided on the main body BD changes, such as hypo- or hypertension, diabetes insipidus, hyperglycemia, hypothermia, infections, corneal ulcers [6].

Cardiac monitoring of PD should be the complete the possible, Ensuring the continuous ECG recording, in addition to other basic vital data such as blood pressure (BP) measurement of Central Venous Pressure (CVP), perfusion analysis, Among others [7].

SAH related to Intracranial Pressure (ICP) should be treated when the systolic blood pressure (SBP) $>180 \mathrm{mmHg}$ and diastolic blood pressure (DBP) > $120 \mathrm{mmHg}$ or Mean Arterial Pressure (MAP) > 95 $\mathrm{mmHg}$. Vasoactive drugs should be controlled infusion, especially sodium nitroprusside. Thus, it is recommended using the infusion pump for control of your drip should be strict. The PA must be continuously monitored [7], preferably from invasive manner. The minimum pressure goal should be MAP> $65 \mathrm{mmHg}$ and SBP> $90 \mathrm{mmHg}$ [8].

To guide fluid replacement, PVC should not be used in isolation but together with the use of dynamic parameters to evaluate responsiveness to 
volume. It is recommended to infuse $500-1000 \mathrm{ml}$ volume when show signs of low flow and PVC $<4$ $\mathrm{mmHg}$. If unresponsive volume according to the dynamic parameters or variation CVP> $2 \mathrm{mmHg}$, interrupting the infusion [8].

In correction volume, Ringer Lactate is the crystaIloid of choice, but the use of saline to $0: 45 \%$, Also good results shows, because the use of Sodium Chloride $(\mathrm{NaCl})$ 0.9\% may cause hypernatremia [7]

The vasoactive drugs to be infused into central veins and volume replacement should be performed through a peripheral large vein to prevent usage quickly by the same routes and minimize the risk of leakage [10].

In the event of Cardiopulmonary Resuscitation (CPR) and taquiarritmies, nurses, along with doctor, should start basic and advanced maneuvers immediately and transport the patient to the operating room for removal of viable organs. Life support measure should be interrupted if the person is not donor of multiple organs and tissues due to the irreversibility of the case, by the process of inquiry No.7.311/97 CFM.

Given the significant increase in the number of transplants in Brazil is still insufficient in relation to the demand for receivers in the queue, and that a small flaw in PD maintenance can undermine the donation and transplantation process, the objective of this study is to identify and analyze the knowledge of nurses regarding the maintenance of the potential donor with brain death before the cardiovascular changes that it may present.

\section{Methods}

Descriptive research with quantitative approach, developed in a large hospital public of Ceará, given that it holds the largest number of potential donors notifications (PD) Organ on Brain Death (BD) the State, according to the Notification Center, Procurement and Distribution of Organs and tissues of Ceará.
The collection of data passed in October and November 2014. The composition of the study population was given by nurses whose practice assists occurred in hospital departments that monitor PD in ME: the Intensive Care Unit (ICU) and Emergency - red axis, which is part of the Parade Room, Room Stabilization and Observation III.

The described units counted during the data collection, 100 nurses, 61 ICU and 39 of the Emergency. As inclusion criteria, there was the nurse who had not been on leave/holiday and that this has already mandatorily provided care to patients with BD. Therefore, we excluded 01 nurses to be on leave/vacation and 03 for not having had contact with patients with BD.

Thus, after application of the inclusion criteria, we obtained a sample of 82 nurses, which showed available for the study, after the explanation of the objectives and methodology and therefore the signing of the Consent Agreement and Informed (IAC).

He proceeded then with the data collection, which occurred in the sectors mentioned above, and was carried out with the use of two instruments: the first was the Botarelli questionnaire adjusted to the subject in order to observe the variables of the research, which contained socio demographic data, professional identification and experience of nurses in care in PD maintenance in $\mathrm{BD}$.

The preparation of the second data collection instrument happened by the researchers, based on the relevant literature to the theme, which was composed of multiple-choice questions, which could have more than one correct option on the assistance to be provided to the PD before the cardiovascular, pulmonary, endocrine-metabolic, hypothalamic, hematological and care related to infectious aspects change. For this article, the data relating to cardiovascular changes were analyzed.

For data analysis, we used the Microsoft-Excel XP software and after tabulating they moved data to SPSS (Statistical Package for Social Sciences) version 20.0 in order to determine, analytically, the 
simple descriptive statistics and standard deviations thereof.

The results were shown in tables and graphs, in which the answers of the nurses were interpreted according to the amount of correct answers for each question, since some questions had more than one correct option. Thus, "Total Adjustment" is that the nurse chose all true items, "partial settlement" denotes that it opted for at least "one" correct item, "missed" infers that this did not indicate any of the valid items, and the option "no response", the participant had no knowledge to give the correct answer or disagreed with the proposed items.

For the study, we hearkened to the ethical and legal principles of research on human subjects governed by Resolution of the National Health Council No. 466 of 12 December 2012.8 as it was approved by the Ethics and Research Committee of the Association unified Paulista Renewed Education through opinion No. 826503 and the Research Ethics Committee of the hospital, with opinion No. 877,387.

\section{Results}

On the socio-demographic profile of the subjects participated in the study 82 nurses, in which the majority was female (81.7\%) with mean age of 35 $( \pm 10)$, the upper limit of 61 and lower limit of 22 years. Most en interviewed were single (42.7\%), without children (62.2\%) and Catholicism (78\%).

Regarding professional characterization and knowledge of nurses on the care of patients diagnosed with BD, 62.2\% had their training in private institution and the remainder (37.8\%) at a public institution. The participating nurses, 54.9\% worked in the ICU sector, $42.7 \%$ in the emergence and $2.4 \%$ in both sectors, with an average of 7 years and 9 meses on the professional uptime.

Of the respondents, only $13.4 \%$ said they did not feel prepared to assist patients diagnosed with $\mathrm{BD}$, while $85.4 \%$ said they were prepared. As a way of obtaining knowledge to assist such patients, the daily practice prevailed in the choice of participants, with $87.8 \%$. The graduation course was chosen by only $15.8 \%$ of nurses as the place where information is gained for that type of assistance. Most nurses (61\%) said that there isn't any obstacle or difficulty to watch this type of patient

On questions related to nursing care on the cardiovascular, $74.3 \%$ stated correctly that the recommended way to monitor the PD in BD be as complete as possible including PVC, $15.9 \%$ stated correctly that BP should be monitored, preferably invasive way, $12.2 \%$ stated erroneously that only BP monitoring and Sat O 2 are already sufficient monitoring and $7.3 \%$ opted also wrongly, only by continuous and Sat 02 electrocardiography, totaling $13.4 \%$ error between the participants, as we observe below, in Table 1.

When nurses were asked whether the systemic arterial hypertension (SAH) should be dealt with PD, $78 \%$ stated correctly that must be addressed when the systolic blood pressure (SBP) is greater than 180 $\mathrm{mmHg}$ and diastolic blood pressure (DBP) is greater than $120 \mathrm{mmHg}$, while $20.7 \%$ said, also correctly, that must be addressed when the Pressure Blood Average (PBA) is greater than $95 \mathrm{mmHg}$. However, $3.6 \%$ incorrectly they chose that SAH should not be treated in PD. This inquiry showed $91.5 \%$ of partial successes (Table 1)

On the minimum pressure goal that must be achieved in the PD in $\mathrm{BD}, 82.9 \%$ of respondents correctly chose q ue the WFP must be greater than $65 \mathrm{mmHg}$ and SBP greater than $90 \mathrm{mmHg}$, while $13.4 \%$ wrongly chose the option that PAM should be higher than $40 \mathrm{mmHg}$ or greater than $70 \mathrm{mmHg}$ SBP totaling $82.9 \%$ of overall hits between responses (Table 1).

On discontinuation of infusion volume for volume replacement in PD, 68.3\% of nurses said correctly that the infusion should be discontinued if unresponsive to volume, according to dynamic parameters, while $26.8 \%$, correctly, that the discontinuation of infusion should be made $s$ and the variation 
Table 1. Classification nurses answers about the item nursing care related to cardiovascular changes of the potential donor. Fortaleza. CE. 2014.

\begin{tabular}{|c|c|c|c|c|c|c|c|c|}
\hline \multirow{2}{*}{ Variable } & \multicolumn{2}{|c|}{ Total hit } & \multicolumn{2}{|c|}{$\begin{array}{l}\text { Partial } \\
\text { Settlement }\end{array}$} & \multicolumn{2}{|c|}{ Missed } & \multicolumn{2}{|c|}{$\begin{array}{l}\text { Did not } \\
\text { answered }\end{array}$} \\
\hline & N & $\%$ & $n$ & $\%$ & $n$ & $\%$ & N & $\%$ \\
\hline How should the monitoring of PD? & 7 & 8.5 & 60 & 73.2 & 11 & 13.4 & 4 & 4.9 \\
\hline Hypertension should be treated in the PD? & 2 & 2.4 & 75 & 91.5 & 4 & 4.9 & 1 & 1.2 \\
\hline $\begin{array}{l}\text { What is the minimum pressure goal should be achieved in } \\
\text { the PD in BD? }\end{array}$ & 68 & 82.9 & - & - & 11 & 13.4 & 3 & 3.7 \\
\hline $\begin{array}{l}\text { During the fluid replacement, when to stop the infusion } \\
\text { volume? }\end{array}$ & 3 & 3.7 & 72 & 87.8 & 6 & 7.3 & 1 & 1.2 \\
\hline $\begin{array}{l}\text { For volume correction, which or what solutions are } \\
\text { recommended? }\end{array}$ & 1 & 1.2 & 70 & 85.4 & 11 & 13.4 & - & - \\
\hline $\begin{array}{l}\text { What is the care that nurses should have in relation to } \\
\text { vasoactive agents and volume replacement? }\end{array}$ & 8 & 9.8 & 46 & 56.1 & 27 & 32.9 & 1 & 1.2 \\
\hline $\begin{array}{l}\text { In case of CPR, which the conduct of the nurse with the } \\
\text { doctor? }\end{array}$ & - & - & 44 & 53.7 & 38 & 46.3 & - & - \\
\hline
\end{tabular}

of Pressure Central Venous (PVC) is greater than 2 $\mathrm{mmHg}$. The option that says about the interruption of the infusion volume when PD present itself hypoflow and PVC less than $4 \mathrm{mmHg}$, was incorrectly chosen by $8.5 \%$ of respondents. The prevalence of this questioning was $87.8 \% \mathrm{~s}$ partial hits (Table 1).

About recommended solutions for volume correction, there were four alternatives. Of these, obtained the highest percentage $(73.1 \%)$ of the correct options on the use of Ringer Lactate. However, the other correct option, which would be 0,45\% saline solution is covered by only $19,5 \%$ of hits (answers) The choice of Sodium Chloride $(\mathrm{NaCl})$ $0.9 \%(39 \%)$ and normal saline serum (6.0\%) were chosen incorrectly. According to the classification of Table 1, the prevalence was partial successes, totaling $85.4 \%$.

About the care that nurses should have in relation to the infusion of vasoactive drugs and the PD volume replacement, $65.8 \%$ stated correctly that s vasoactive drugs should be infused in central veins, and only $20.7 \%$ the volume replacement should be performed through a peripheral large vein. However, $60.9 \%$ of respondents said incorrectly that va- soactive drugs and volume replacement should be infused into central veins and $6.0 \%$ that to vasoactive drugs and volume replacement should be carried out through veins different peripheral caliber. This inquiry showed $56.1 \%$ of partial successes.

Regarding the conduct of the nurse with the doctor in the event of Cardiopulmonary Resuscitation (CPR), the most preferred option among nurses was the only incorrect option of questioning, which states that the PD can't be revived, totaling $63.4 \%$. Only $37.8 \%$ said correctly that they should reinitiate advanced maneuvers immediately and $15.8 \%$ should interrupt the support measures if the family refuse the donation of organs, totaling 46.3\% error between responses as described below in Table 1.

\section{Discussion}

Several researches claim more than half the audience of nurses Consists of female professionals, corroborating the present date. Since the early days of the profession, this characteristic historically plays the nursing [12]. 
One survey aimed to verify the knowledge of nursing professionals about $\mathrm{BD}$ and maintenance of PD, in which the majority (58.2\%) of the 55 nursing professionals who participated in the study also said they were prepared to meet the PDs, with data similar to this research, where the majority (85.4\%) also said he was prepared to care for these patients [13].

Few answers about the degree course as a source of knowledge acquisition, with only $15.8 \%$, denotes a concern about the influence of academic training in nursing practice these professionals, supporting the literature findings that claim in a short approach subject in undergraduate nursing courses. There is still a gap in the education of students on the topic of organ donation and understanding of $\mathrm{BD}$ is flawed for most, beyond the small number of postgraduate courses that address the issue [14].

Similar data Were Also found in the study Botarelli, in the city of Natal, in order to identify the nurse 's knowledge about the process of care for the patient victim of head trauma, the pre hospital and hospital stages. Of the 44 nurses interviewed, only 8 (10.67\%) said They have acquired knowledge on the subject in the degree course.

The participating nurses in the current study, a minority (39\%) said there is difficulty or impediment to assist these patients, no corroborating data from a survey cited above, where the majority (61.8\%) of 55 nursing professionals interviewed, They said that there are obstacles that hinder the assistance PD, among them, the most mentioned was the unpreparedness of staff (34.6\%) [15].

Different data were also found in a study conducted in the ICU of a hospital in southern Brazil, which sought to understand the perceptions of the nursing team in his role in patient care in BD. The study included 26 professionals of the nursing team, of which, $57.7 \%$ reported having some difficulty in patient care in BD. The difficulties reported by the subjects were: the relationship with the family of $P D$, logistical and administrative structure of the institution acceptance of BD and lack of knowledge in relation to patient care in BD [16].

About nursing care related to cardiovascular, cardiac monitoring PD should be as complete as possible, ensuring the continuous ECG recording, in addition to other basic vital data such as blood pressure (BP) measurement of Central Venous Pressure (PVC), perfusion analysis, among others. Preferably, the BP needs to be monitored invasive manner, for noninvasively may be inaccurate. In addition, the blood collecting facilitates access to graded blood samples and permits the use of dynamic fluid responsiveness parameters [17].

The documentary research carried out in a hospital in Sergipe, in order to meet the nursing care provided to the PD, record 24 records. Of these, only $12.50 \%$ had CVP monitoring record, $83.33 \%$ used the multiparameter monitor, $41.67 \%$ had BP records noninvasive and record of $37.50 \%$ heart rate, showing gaps in relation to the registration of such assistance, not ensuring that the best care is provided [18].

The initial event in BD is characterized with increased ICP associated with cardiovascular and systemic dysfunction. During the autonomic discharge in $B D$, the sharp release of catecholamines, associated with increased ICP, produces vasoconstriction, resulting in tachycardia, increased BP and myocardial oxygen demand and may result in ischemia and myocardial necrosis, and cardiac arrhythmias. Therefore, hypertension related to this phase of evolution of the $B D$, called sympathetic storm, should be treated when the systolic blood pressure (SBP) is greater to 180 $\mathrm{mmHg}$ and diastolic blood pressure (DBP) is greater than $120 \mathrm{mmHg}$ or Mean Arterial Pressure (MAP) is greater than $95 \mathrm{mmHg}$. the vasoactive drugs should be controlled infusion, especially sodium nitroprusside. Thus, it is recommended using the infusion pump for control of your drip must be strict [19].

In a documentary research, as quoted above, in which the nursing care provide to PD through 24 records registry were analyzed in only $20.83 \%$ had 
record related to the use of infusion pump for volume management control and drugs [20].

After cease friendly storm, the result is the loss of sympathetic tone, with deep vasodilation, loss of compensatory mechanisms and severe hypotension, which is the most serious and frequent physiological change of BD. Therefore, nurses should be aware as to the parameters of Mean Arterial Pressure (MAP) or Systolic Blood Pressure (SBP), which should be kept above $65 \mathrm{mmHg}$ and $90 \mathrm{mmHg}$, respectively [21].

The lack of viable parameters to maintain PD was the most emphasized difficulties related to lack of knowledge in the care of these patients, among other difficulties that were reported by $57.7 \%$ of the 26 nurses who participated in a survey already mentioned above [10].

In the present study, on the issues of the pressure parameters, $91.5 \%$ of participants had partial knowledge in relation to the parameters recommended maximum target pressure, and $82.8 \%$ had full knowledge related to minimum pressure goal.

The blood loss resulting from trauma, inadequate resuscitation, the use of osmotic treatment for intracranial hypertension, hypothermia, electrolyte and hormonal disorders also contribute to low blood pressure, which if not treated properly and expeditiously, may trigger other important complications, leading to decreased perfusion of various organs and even cardiac arrest. [17]

As cardiovascular hypotension requires support in euvolemia, the first therapeutic measure is the administration of fluids to keep the plasma volume.

To guide fluid replacement, PVC should not be used in isolation but together with the use of dynamic parameters to assess fluid responsiveness. It is recommended to infuse 500-1000 $\mathrm{ml}$ volume when show signs of reduced blood flow and PVC less than $4 \mathrm{mmHg}$. The nursing staff should be alert when unresponsive to volume, according to dynamic parameters or the change of PVC is greater than $2 \mathrm{~mm} \mathrm{Hg}$, should stop the infusion. Among the 82 participants of current research nurses, $8.5 \%$ chose incorrectly the option that says about the interruption volume when the PD present signal of hypoflow and PVC less than $4 \mathrm{mmHg}$, when in reality should be infused volume and not interrupting your infusion [15].

In volume correction, Ringer Lactate is the crystalloid of choice, but the use of saline to $0.45 \%$, also shows good results. Use of Sodium Chloride ( $\mathrm{NaCl}$ ) $0.9 \%$ was incorrectly chosen by $39 \%$ of respondents, but its use is not recommended in PD due to the risk of causing hypernatremia. [13].

The nursing team has the responsible care with the infusion of vasoactive drugs and volume replacement. The vasoactive drugs to be infused into central veins and volume replacement should be performed through a peripheral large vein to prevent usage quickly by the same routes and minimize the risk of extravasation ${ }^{13}$. It is noteworthy that in this study, $32.9 \%$ of nurses surveyed did not choose any of the options presented in the correct questions about this care.

In the event of Cardiopulmonary Resuscitation (CPR) and taquiarritmies, nurses, along with the doctor, should start basic and advanced maneuvers immediately to maintain the viability of organs to be donated, in addition to the transport to the operating room for removal of viable organs. During the maintenance phase, approximately $10 \%$ of all PDs experience cardiac arrest you need the basic and advanced resuscitative immediate maneuvers, which must follow traditional protocols. It should be remember that bradycardia unresponsive to atropine in the presence of $\mathrm{BD}$, due to the absence of vagal activity, and recommends the use of adrenaline, dopamine or isoproterenol [3].

Supportive measures should be discontinued when no donor of multiple organs and tissues due to the irreversibility of the case, according to Resolution of the Federal Council of Medicine $n^{0} 1.826$ / 2007. After the diagnosis of BD, the patient is considered under the legal aspect, moral and ethi- 
cal, a corpse. Respect should be maintained, but the therapeutic institution is futile [19]. After the diagnosis of BD, cardiac arrest occurs between a week, but there are cases described in these patients remained generating unnecessary expenses and occupying ICU beds for nearly two months, and generate suffering family [9].

Although most have partially answered correctly $(53.7 \%)$ on the conduct of the nurse with the doctor in the event of PCR, we draw attention to the large percentage (63.4\%) who said that the PD does not It can be reanimated. Only $37.8 \%$ said they should start basic and advanced maneuvers immediately, and a small percentage (15.8\%) correctly chose the option of stopping the support measures if the family refuses to organ donation.

The data presented corroborate in part to a study conducted in 2010 with 55 nursing professionals from the sectors of ICU and Emergency at a hospital in the city of Natal, in which a high percentage (47.3\%) responded that the PD can not be reanimated, although the majority (52.7\%) have correctly stated that yes can be reanimated. In addition, $50.9 \%$ of professional participants stated correctly on disrupting supportive measures if the family refuses to organ donation [9].

It is important to point out that the vast majority (85.4\%) of nurses surveyed said they feel prepared to assist the PD, however, when related to the findings on the knowledge of those nurses in the PD nursing care on cardiovascular changes of BD, realize it is known that this is not the reality. This finding corroborates a study already quoted above, in which $58.2 \%$ of nurses said they were prepared to meet the PDs, but the result of the study has not demonstrated that reality.

\section{Conclusion}

With respect to questions of nursing care on the cardiovascular, $74.3 \%$ of nurses said correctly that the recommended way to monitor the PD for $\mathrm{BD}$ should be as complete as possible including PVC, $15.9 \%$ stated correctly that BP should be monitored, preferably invasive way, $12.2 \%$ stated erroneously that only BP monitoring and Sat O 2 are sufficient in monitoring and $7.3 \%$ opted also wrongly, only by continuous electrocardiography and Sat $\mathrm{O} 2$, totaling $13.4 \%$ error between the participants.

As the results, it was observed that nurses possess a level of partial knowledge about care to the potential organ donor on their cardiovascular changes. Even though, same obtained $85.4 \%$ of the positive statements with regard to security in the care to be provided to the PD with these types of changes.

Thus, the nurse must develop essential skills to the complexity of care in PD, but also to act in various stages of transplantation (Pre, during and after), ambulatory monitoring of the living donor or not, professional development, professional practice and ethics.

As we saw earlier, cardiovascular changes may result in deleterious effects that may impair the quality of the structures to be donated. Therefore, it is vitally important to prepare nurses to provide adequate assistance to the care of the organ to be donated.

Concludes, finally, that health institutions need to invest in the training of nurses providing direct care to patients with brain death who are potential donors of organs and tissues, as this issue is rarely addressed in the course of graduation. Such investment will bring uniformity in professional conduct, with a view to better preparation of nurses to deal with the patient, affecting the improvement of care and increasing the number of effective funding.

\section{References}

1. Souza SS, Borenstein MS, Silva DMGV, Souza SS, Carvalho JB. Nursing coping strategies in the care of potential organ donor Rene. [online]. Jan.-feb. 2013; 14(1) [access on 10 march. 2014]: 92-100. Available from: http://www.revistarene.ufc.br/revista/ index.php/revista/article/view/96/pdf 
2. Brazil. Federal Nursing Council. COFEN Resolution N 292/2004. Regulates the performance of the nurse in the capture and Transplantation of Organs and Tissues. [online] Rio de Janeiro (RJ jun 7, 2004 [accessed 04 mar. 2014]. Available from: http:// www.saude.ba.gov.br/transplantes/documentos tx/cofen.pdf

3. Brazilian Association of Organ Transplantation. Registry of Transplants-RBT[online]. São Paulo: ABTO; Jan-dec 2013; Year XIX (4). [access on 10 mar. 2014] Available from: http:// www.abto.org.br/abtov03/Upload/file/RBT/2013/rbt2013parcial\%281\%29.pdf

4. Dalbem GG, Caregnato RCA. Organ Donation for transplantation: rejection of families. Text context - enferm. [online]. Dec 2010 [access in 06 dec. 2014]; 19(4): 728-35. Available from: http:// www.scielo.br/pdf/tce/v19n4/16.pdf

5. Soler, W.V. Basic Guidelines for Funding and withdrawal of multiple Organs and Tissues of the Brazilian Association of Organ Transplantation / São Paulo: ABTO - Brazilian Association of Organ Transplantation, 2009.

6. Ministry of Health (BR). National Transplant Systems-NTS. [online]. Brasília (DF). [Access 04 march. 2014] Available from http://dtr2001.saude.gov.br/sas/dsra/integram.htm

7. Botarelli, F.R. Knowledge About Nurse Patient Care Process with Traumatic brain injury [dissertation]. [online]. Natal: Universidade Federal do Rio Grande do Norte. Departament of Nursing; 2010 [Access 09 march. 2014]. Available from: http://repositorio.ufrn. br:8080/jspui/bitstream/1/9235/1/FabianeRB DISSERT.pdf

8. Ministry of Healthe (BR). Conselho Nacional de Saúde, Comissão Nacional de Ética em Pesquisa-CONEP. Resolution n 466/12, About Guidelines and Regulatory standards for research involving human subjects. Brasília (DF); 2012.

9. Freire ILS, Mendonça AEO, Pontes VO, Vasconcelos QLDAQ, Torres GV. Brain death and care in maintaining the potential donor of organs and tissues for transplatation. Eletr. Nursing Journal. [online]. Dec 2012 [Access 09 march. 2014]; 14(4): 903912. Available from: http://www.fen.ufg.br/fen revista/v14/n4/ pdf/v14n4a19.pdf

10. Lima Camila Santos Pires, Batista Ana Cláudia de Oliveira, Barbosa Sayonara de Fátima Faria. Nursing staff perception in patient care in brain death. Eletr. Nur. Journal. [Serial on the internet]. 2013 Sep [2015 Fev 28 mentioned]; 15(3): 780-789. Available from: http://www.revenf.bvs.br/pdf/ree/v15n3/21.pdf

11. Cavalcante Layana de Paula, Ramos Islane Costa, Araújo Michell Ângelo Marques, Alves Maria Dalva dos Santos, Braga Violante Augusta Batista. Patient nursing care in brain death and potential organ donor. Acta paul. enferm. [serial on the Internet]. 2014 Dec [cited 2015 Feb 28]; 27(6): 567-572. Available from: http:// www.scielo.br/pdf/ape/v27n6/1982-0194-ape-027-006-0567.pdf

12. Cicolo Emilia Aparecida, Roza Bartira de Aguiar, Schirmer Janine. Donation and transplantation: scientific production of Brazilian nursing. Rev. bras. enferm. [serial on the Internet]. 2010 Apr [cited 2015 Feb 28]; 63(2): 274-278. Available from: http://www.scielo.br/pdf/reben/v63n2/16.pdf

13. CARVALHO, AYC et al. Pathophysiological changes in brain death and nursing care: a literature review. JBT - J Bras Transpl, São Paulo. V.14, n.2, p.1533-1537, april/jun 2011
14. Fagioli FGD, Botoni FA. Treatment of potential donor of multiple organs. Rev. méd. Minas Gerais [online]. Jul-Sep. 2009; 19(3) [Access 09 march. 2014] Available from: http://rmmg.medicina. ufmg.br/index.php/rmmg/article/view/166/149

15. Westphal GA, Caldeira FM, Vieira KD, Zaclikevis VR, Bartz MCM, Wanzuita R et al. Guidelines for maintenance of multiple organs in adult deceased potential donor:Part I. Overview and hemodynamic support. Rev. bras. ter. intensiva [online]. Sep 2011 [Access 10 march. 2014]; 23(3): 255-68. Available from: http://www.scielo.br/pdf/rbti/v23n3/v23n3a03.pdf

16. Fonseca ATA, Costa VAS, Nogueira EC. Nursing cara to potential organs and tissue donor: Records of hospital in Sergipe. JBT - J BrasTranspl. [online]. Jan-mar. 2011 [Access 09 mar. 2014]; 14(1): 1460-65 Available from: http://www.abto.org.br/abtov03/ Upload/file/JBT/2011/1.pdf

17. Freire SG, Freire ILS, Pinto JTJM, Vasconcelos QLDAQ, Torres GV. Physiological changes of brain death in potential organ and tissues donor for transplatations. Esc. Anna Nery [online]. Dec 2012 [Access 04 mar. 2014]; 16(4): 761-66. Available from: http://www.scielo.br/pdf/ean/v16n4/17.pdf

18. Federal Council of Medicine. Resolution CFM n¹.826, 24 out. 2007. Diário Oficial da União, Brasília-DF, 06 dec. 2007. Section I, p.133 http://www.einstein.br/Ensino/cursos-de-atualizacao/ Documents/resolucao-cfm-1826-2007.pdf

19. Morato, EG. Brain death: essential concepts,diagnosis and update. Morte encefálica: conceitos essenciais, diagnóstico e atualização. Rev. méd. Minas Gerais [online]. Jul-sep. 2009;19(3) [Access 04 mar. 2014] Available from: http://www.fisfar.ufc.br/ petmedicina/images/stories/artigo morte enceflica.pdf

20. ABADIE, Alberto; GAY, Sebastien. The impact of presumed consent legislation on cadaveric organ donation: a cross country study. J Healthy Econ. v. 25, n. 4, p. 599-620, Dec. 2005. Access 14 jul. 2016. 10.1016/j.jhealeco.2006.01.003.

21. Negreiros FDS, Marinho AMCP, Garcia JHP, Morais APP, Aguiar MIF, Carvalho SL. Donor liver uptake for transplatation: A roposed protocol for nurses. Esc. Anna Nery. 2016;20(1):38-47
Publish in International Archives of Medicine

International Archives of Medicine is an open access journal publishing articles encompassing all aspects of medical science and clinical practice. IAM is considered a megajournal with independent sections on all areas of medicine. IAM is a really international journal with authors and board members from all around the world. The journal is widely indexed and classified Q2 in category Medicine. 